\title{
Can financial literacy become an effective mediator for investment intention?
}

\author{
Kelvin Tanuwijaya ${ }^{a}$ and Ignatius Roni Setyawan ${ }^{b^{*}}$
}

${ }^{a}$ Alumnae of Faculty of Economic and Business, Tarumanagara University, Indonesia ${ }^{b}$ Lecturer of Faculty of Economic and Business, Tarumanagara University, Indonesia

\begin{tabular}{l}
\hline C H R O N I C L E \\
\hline Article history: \\
Received: February 27, 2021 \\
Received in revised format: \\
April 292021 \\
Accepted: May 16, 2021 \\
Available online: \\
May 18, 2021 \\
\hline Keywords: \\
Financial Socialization \\
Financial Experience \\
Financial Literacy \\
Investment Intention \\
College Students
\end{tabular}

\section{A B S T R A C T}

The lifestyle of Indonesian people who are very consumptive makes it difficult for people to invest. This can be shown in the number of capital market investors in Indonesia which is only $0.61 \%$ of the total population. The low level of financial literacy in Indonesia is one factor. Many people do not understand finance so they cannot manage finances properly. In this study, we look for 130 respondents who are college students to find out how financial socialization and financial experience influence on investment intention through financial literacy. The theory used in this research is theory of planned behavior and social learning theory. In this study, financial literacy can only mediate the financial experience of investment intention. The results of this study are in accordance with the theory of planned behavior in which one of the elements is perceived behavioral control with self-control factors originating from within, namely experience so that the financial experience is expected to generate interest in investing.

\section{Introduction}

Every human being would want to meet the needs and desires that are very diverse and endless, especially people who live in Jakarta. The demands and lifestyle in Jakarta is one of the problems faced by every community. With the high standard of living in Jakarta, people are also trying to earn a high income. Every month, most of the people of Jakarta spend most of their income on their needs and lifestyles, which are classified as consumptive. According to the Manulife Investor Sentiment Index (2016), $53 \%$ of respondents spend $70 \%$ of their income to meet their needs and desires and $10 \%$ of respondents spend $90 \%$ of their income. Based on economic theory, a person's income can be allocated into consumption, savings and investment. Haming and Basamalah (2010: 14) say that investment is the current expenditure in the hope that it will get greater returns in the future. Investing can prevent the consumptive lifestyle of the people of Jakarta. Instruments for investing are very diverse, ranging from physical ones such as precious metals and non-physical property or financial instruments such as bonds, stocks, deposits and mutual funds. Of all the above instruments, stock is one investment instrument that has a high enough return when compared to other instruments. According to the Indonesian Central Securities Depository (2018), the number of Single Investor Identification (SID) in Indonesia has increased from year to year. In 2018, KSEI noted that Indonesia had 1,617,367 SID or $0,61 \%$ of the total population of Indonesia. But when compared with Malaysia 3.8 million investors or the equivalent of $12.8 \%$ of the population and Singapore 1.5 million investors or the equivalent of $30 \%$ of the population. From these data, the phenomenon arises why the number of stock investors in Indonesia is not less than $1 \%$ of the entire population of Indonesia. One of the main factors influencing investment interest is financial literacy supported by OJK survey evidence (2018) which shows the results of the financial literacy level of Indonesian people around $21.84 \%$ for 2016 and OJK targets the financial literacy rate of Indonesian people to reach 35\% in 2019 This will certainly have a good impact on the development of financial products in Indonesia, including investment.

\footnotetext{
* Corresponding author.

E-mail address: ign.s@fe.untar.ac.id (I. R. Setyawan)

(C) 2021 by the authors; licensee Growing Science, Canada doi: $10.5267 /$ j.ac. 2021.5 .011
} 
According to Al-Tamini and Anood's research (2009) with respondents of UAE investors, there is a positive relationship between financial literacy and investment decisions which explains that the higher a person's financial literacy will encourage someone to invest and choose the right investment instrument. One of the factors that makes someone have an interest in investing because that person already understands the principles of finance. Every year, the country is always faced with inflation. With inflation, it will certainly increase the price of goods and make our currency smaller. One way to overcome inflation is to invest in order to get results in order to maintain or increase the value of your money. In addition, based on Mahfudh's (2014) research from investor respondents in Kenya shows that investors in the Kenyan capital market are investors who have sufficient financial literacy. From the two similar studies, it still needs to be re-examined with different respondents namely students of the Faculty of Economics and Business, Tarumanagara University, whether they can show similar results as well. To measure someone's literacy level, it can be determined by several factors such as financial socialization and financial experience. Based on Ameliawati \& Setiyani's research (2018) that financial socialization can influence financial management behavior (Ajzen \& Fishbein, 1977) through financial literacy that is strengthened by social learning theory. In this study, social agents become one of the sources of someone obtaining financial literacy knowledge that can influence their financial management behavior. The agents who can play an important role include: parents as the main agent, friends and the environment around us who become complementary agents. The relationship between financial experience and financial behavior through financial literacy according to Ameliawati \& Setiyani's research (2018), shows positive results, which means that the more financial experience a person has, the better the financial behavior will affect. In this case, a person's experience becomes a very important factor influencing financial management behavior. Where, the more financial experience that is owned then makes a person become higher in the level of financial literacy so that it can make a person's financial behavior better. Students are agents of change who will continue the struggle of this nation including undergraduate students at Tarumanagara University, Faculty of Economics and Business Jakarta, who will graduate and become economic actors in the community. In the long run these students will be central in economic activity. Based on data from KSEI (2018), it is said that the majority of investors in the capital market come from the age of $21-30$ years $(39.72 \%)$ of $51.42 \%$ with a bachelor education background. Thus this study is to test the effect of financial socialization and financial experience on investment intention through financial literacy on college students. Or in other words, this study wants to test the effectiveness of financial literacy as a mediating variable of the two determinants of investment intention to target student respondents.

\section{Literature review}

A number of studies relating to the theme of investment interest explain the factors influencing one's investment interest and their relationship. The initial concept of this study adopted and adapted from previous studies that have links between research results and research methods. Mahfudh (2016) conducted research on investors at The Nairobi Securities Exchange using a questionnaire that took a sample of 400 respondents using non-probability sampling techniques, with the result that there was a significant relationship between financial literacy and the investment decision making process. Research by Muhammad and Khan (2018) which took samples of students, lecturers, and individuals who have investment experience. The number of respondents taken was 310 respondents using non-probability sampling techniques through questionnaires. From this study the results showed that there was a significant positive relationship between financial literacy and investment intention. Kumar et al. (2017) conducted a study with 337 respondents from President University students using a non-probability sampling technique through a questionnaire which revealed that there was a significant positive relationship between financial literacy and financial behavior. The research of Ameliawati and Setiyani (2018) which took a sample of Semarang University Faculty of Economics students through questionnaires with 278 respondents using non-probability sampling techniques. The results of this study indicate that there is a positive relationship between financial socialization of financial behavior through financial literacy, as well as a positive relationship between financial experience and financial behavior through financial literacy. Copur (2011) conducted research with Hacettepe University students as 3983 respondents by distributing questionnaires. The results of this study say that a student who conducts financial consultations with parents becomes materialistic than those who do not consult. Palm (2017) examined by taking a sample of 283 respondents from South Dakota State University through a questionnaire. The results of this study are that there is no influence between financial socialization on the use of credit cards among students. The social agent in question is the parent in this study. Lusardi and Tufano (2009) conducted research in collaboration with Taylor Nelson Sofres (TNS) Global by telephone as a data collection tool. Samples taken as many as 1000 people. The results of this study say that the more financial experience a person has, the more a person will become aware of financial concepts such as making credit card payments on time to avoid interest. White and Fulk (2018) conducted a study with a sample of 5729 Ohio Student Financial Wellness Study (OSFWS) students. Based on this study, it was concluded that the majority of OSFWS students consulted their parents about their financial condition. Ali (2011) conducted a study by taking samples of 341 students majoring in investment management and portfolio with non-probability sampling techniques. The results of the study indicate that perceived risk, perceived return, and trust can positively affect the investment interest so that it can be interpreted that the smaller the risk, the greater the return promised and the trust offered makes a person have an interest in investing in the instrument. Solheim et al. (2011) conducted a study by taking 217 Midwest University students with non-probability sampling techniques. From this study the results obtained show that students who pay attention to their parents as role models in finance have a level of awareness to save and manage finances well. Another study took a sample of the workforce in Malaysia and successfully obtained 1957 respondents. This study uses a non-probability sampling technique. The results of this study show that the higher the level of financial literacy, the better the workforce will be in managing their finances. 


\subsection{Effect of Financial Socialization on Investment Intention}

To get a good level of literacy, social agents are needed to provide good financial information. Social agents in question such as parents and friends. According to the research of Setiyani and Ameliawati (2018), there is a positive influence between financial socialization on financial literacy. Research by Sohn et al. (2012) and Putri and Djuminah (2016) which concluded that the more social agents that are owned will increase one's level of financial literacy. According to Muhammad and Khan (2018) said that there is a positive relationship between financial literacy and investment intention so that the higher the level of financial literacy, the more interested someone will be to invest.

Based on the explanation above, the researcher formulated the hypothesis as follows:

Ha1: There is a significant positive relationship between financial socialization and investment intention.

Ha2: There is a positive significant relationship between financial socialization with investment intention through financial literacy as mediation.

\subsection{Effect of Financial Experience on Investment Intention}

Experience is the best learning material included in the process of increasing the level of financial literacy. According to the research of Setiyani and Ameliawati (2018), there is a positive influence between financial experience and investment intention. Sohn et al. (2012) research also revealed the same results, namely there is a positive relationship between financial experience and investment intention. A financial experience is an important factor in measuring a person's level of financial literacy, there will also be no meaning to someone having a high level of financial literacy without sufficient financial experience. According to Muhammad and Khan (2018), there is a positive relationship between financial literacy and investment intention.

Based on the explanation above, the researcher formulated the hypothesis as follows:

Ha3: There is a significant positive relationship between financial experience and investment intention.

Ha4: There is a significant positive relationship between financial experience and investment intention through financial literacy as mediation.

\subsection{Effect of Financial Socialization on Financial Literacy}

Social agents have an important role in the development of one's financial capabilities. These social agents convey various financial information that can improve financial capacity. According to Ameliawati and Setiyani (2018), there is a positive relationship between financial socialization and financial literacy.

Based on previous research, researchers conclude the following hypothesis:

Ha5: There is a significant positive relationship between financial socialization and financial literacy.

\subsection{Effect of Financial Experience with Financial Literacy}

A person's financial experience will certainly have a good influence on financial ability. The more literate a person has, the more understanding someone is about financial concepts. Financial ability will also depend on the size of the factor in the availability of funds that a person has. For the proxy of the availability of funds, it can be seen in the study of Setyawan (2020). According to Ameliawati and Setiyani (2018), there is a positive relationship between financial experience on financial literacy.

Based on previous research, researchers conclude the following hypothesis:

Ha6: There is a significant positive effect between financial experience on financial literacy.

\subsection{Effect of Financial Literacy with Investment Intention}

Financial literacy is one of the indicators to generate interest in someone to invest. According to research Sadiq and Khan (2018), said that there is a positive relationship between financial literacy on investment intention.

From previous research, researchers formulated the hypothesis as follows:

Ha7: There is a significant positive relationship between financial literacy on investment intention. 


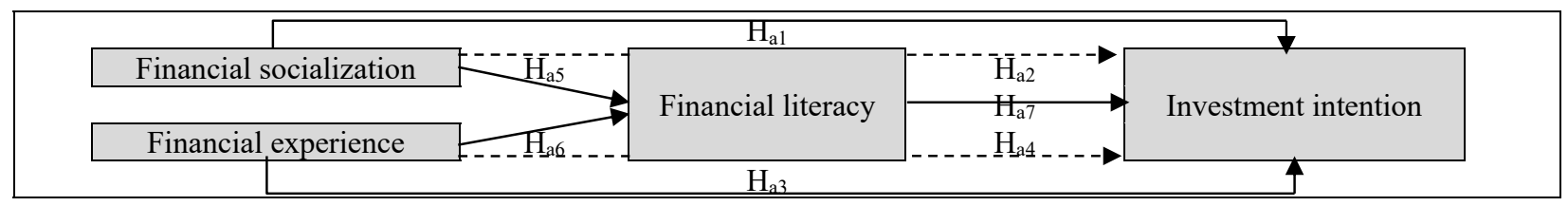

\section{Research method}

Fig. 1. Conceptual framework of the study

\subsection{Data Collection}

In this study, the selected population was Tarumanagara University students. The researcher uses a non-probability sampling technique with a purposive sampling method using the specified criteria. The sample criteria chosen by the researchers were students of the Faculty of Economics and Business, Tarumanagara University who were still active with a minimum level of education at semester 4. According to Ringle and Sarstedt (2011: 7), the condition for the number of samples that must be obtained in using PLS-SEM is ten times the highest number of direct indicators in measurement. In this study, the most measurement indicators are seven indicators so that the minimum sample size is seventy respondents. And according to Roscoe (1975) in Sekaran and Bougie (2013) that is a good number of samples ranging from 30 to 500 samples so that the respondents determined in this study were 130 respondents to meet the rules set.

\subsection{Operational Variable Definition}

In this study, the variables used can be divided into three namely independent, dependent, and mediating variables. The independent variable is the variable that influences the dependent variable, while the mediating variable is the variable that mediates the independent variable to influence the dependent variable. The independent variables in this study are financial socialization and financial experience. The dependent variable is investment intention, and the mediating variable is financial literacy. Each variable can be measured through several indicators using a Likert scale with a score between 1-5. Financial socialization is the process of learning financial sciences obtained from various social agents around individuals. According to Copur (2011) financial socialization can be measured in four indicators, and according to Palm (2017) using four indicators to measure financial socialization. In this study, researchers used six indicators adapted through Copur (2011) and Palm (2017). Financial experience is the knowledge and financial knowledge gained by someone by trying and experiencing various financial events directly in life. Indicator questions to measure the financial experience of this study were adapted from Lusardi and Tufano (2008). Financial literacy is the ability of a person to understand and be able to implement these financial concepts by using financial information available in their lives with the aim of achieving prosperity in the future. The indicator used to measure financial literacy was adapted from the study of Kumar et al. (2017). Interest in investing in shares is an encouragement from within individuals that will lead to the intention to commit to allocate the amount of money owed into a company in return for obtaining a number of company ownership rights as well as profits that depend on the amount of money invested in the company. The question indicator used to measure investment intention was adapted from the research of Ali (2011) as many as seven questions. Convergent validity is the inside of the outer model used to see how much the measurement instrument is related to other instruments. Convergent validity must assume that each indicator in a construct has a high correlation. The rules for assessing convergent validity can be obtained from average variance extracted (AVE) and loading factors. What measurement instrument can be said to be valid if the AVE value $>0.50$ (Henseler et al., 2009) and has a loading factor $>0.50$ (Abdillah \& Jogiyanto, 2015). Discriminant Validity has the principle that the construct measurement tool must not have a low correlation among other construct indicators. Discriminant validity indicators can be assessed from the cross loading value of each indicator and the criteria for the larvalker. Indicators declared passed discriminant validity with the cross loading value of each indicator is greater than the cross loading value of the variable, and the fornell-lacker analysis shows the AVE value of each construct is greater than the correlation between constructs. (Chin, 1998; Chin \& Newsted, 1999; Henseler et al., 2009).

The next stage is the reliability test where this test is used to prove the level of accuracy and consistency of each indicator to measure a construct. This test looks at the value of composite reliability and Crombach's alpha. An instrument can be said to be reliable by looking at the value of composite reliability that exceeds 0.7 (Henseler et al., 2009). Abdillah and Jogiyanto (2015) say that an instrument can be said to be reliable if the value of Crombach's Alpha is greater than 0.6. Convergent Validity is a part in testing the outer model that is used to see how the influence of one indicator with other indicators. An indicator that can be declared valid if it has a high correlation between the indicators in a construct model. To assess convergent validity can be seen from the value of Average Variance Extracted (AVE) and loading factor. According to Henseler et al (2009), a AVE value greater than 0.50 can meet the requirements of convergent validity and according to Abdillah \& Jogiyanto (2015), the loading factor value must be greater than 0.50 to meet the convergent validity requirements. The next stage is the reliability test where this test is used to prove the level of accuracy and consistency of each indicator to measure a construct. This test looks at the value of composite reliability and Crombach's alpha. An instrument can be said to be reliable by looking at the value of composite reliability that exceeds 0.7 (Henseler et al., 2009). Abdillah and Jogiyanto (2015) say that an instrument can be said to be reliable if the value of Crombach's Alpha is greater than 0.6. 
Table 1

Convergent Reliability Results

\begin{tabular}{|c|c|c|c|c|}
\hline & Indicator & Factor Loading & Cronbach's Alpha & Average Variance Extracted (AVE) \\
\hline \multirow{6}{*}{$\begin{array}{c}\text { Financial } \\
\text { Socialization }\end{array}$} & FS1 & 0.770 & \multirow{6}{*}{0.842} & \multirow{6}{*}{ 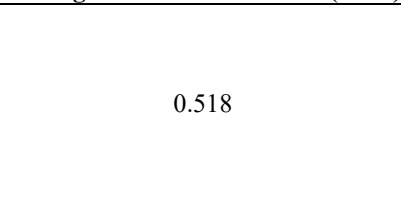 } \\
\hline & FS2 & 0.823 & & \\
\hline & FS3 & 0.789 & & \\
\hline & FS4 & 0.524 & & \\
\hline & FS5 & 0.728 & & \\
\hline & FS6 & 0.773 & & \\
\hline \multirow{7}{*}{ Financial Experience } & FE1 & 0.775 & \multirow{7}{*}{0.913} & \multirow{7}{*}{0.662} \\
\hline & FE2 & 0.556 & & \\
\hline & FE3 & 0.630 & & \\
\hline & FE4 & 0.796 & & \\
\hline & FE5 & 0.699 & & \\
\hline & FE6 & 0.760 & & \\
\hline & FE7 & 0.785 & & \\
\hline \multirow{7}{*}{ Financial Literacy } & FL1 & 0.851 & \multirow{7}{*}{0.832} & \multirow{7}{*}{0.549} \\
\hline & FL2 & 0.667 & & \\
\hline & FL3 & 0.699 & & \\
\hline & FL4 & 0.864 & & \\
\hline & FL5 & 0.893 & & \\
\hline & FL6 & 0.857 & & \\
\hline & FL7 & 0.835 & & \\
\hline \multirow{7}{*}{ Investment Intention } & II1 & 0.707 & \multirow{7}{*}{0.847} & \multirow{7}{*}{0.523} \\
\hline & II 2 & 0.800 & & \\
\hline & II3 & 0.669 & & \\
\hline & II4 & 0.597 & & \\
\hline & II5 & 0.833 & & \\
\hline & II6 & 0.620 & & \\
\hline & II7 & 0.799 & & \\
\hline
\end{tabular}

Table 2

Discriminant validity - Fornell-Larcker criterion

\begin{tabular}{|c|c|c|c|c|}
\hline & $\begin{array}{c}\text { FINANCIAL } \\
\text { EXPERIENCE }\end{array}$ & $\begin{array}{l}\text { FINANCIAL } \\
\text { LITERACY }\end{array}$ & $\begin{array}{c}\text { FINANCIAL } \\
\text { SOCIALIZATION }\end{array}$ & $\begin{array}{l}\text { INVESTMENT } \\
\text { INTENTION }\end{array}$ \\
\hline FINANCIAL EXPERIENCE & 0.720 & & & \\
\hline FINANCIAL LITERACY & 0.664 & 0.814 & & \\
\hline FINANCIAL SOCIALIZATION & 0.690 & 0.650 & 0.741 & \\
\hline INVESTMENT INTENTION & 0.649 & 0.647 & 0.713 & 0.723 \\
\hline
\end{tabular}

Note: Squared correlations; AVE values bolded and located along the diagonal line.

Table 3

Discriminant validity - HTMT criterion

\begin{tabular}{|c|c|c|c|c|}
\hline & FINANCIAL EXPERIENCE & $\begin{array}{l}\text { FINANCIAL } \\
\text { LITERACY }\end{array}$ & $\begin{array}{c}\text { FINANCIAL } \\
\text { SOCIALIZATION }\end{array}$ & INVESTMENT INTENTION \\
\hline FE1 & 0.775 & 0.605 & 0.565 & 0.564 \\
\hline FE2 & 0.556 & 0.317 & 0.369 & 0.373 \\
\hline FE3 & 0.630 & 0.367 & 0.350 & 0.346 \\
\hline FE4 & 0.796 & 0.580 & 0.715 & 0.551 \\
\hline FE5 & 0.699 & 0.401 & 0.346 & 0.375 \\
\hline FE6 & 0.760 & 0.519 & 0.468 & 0.527 \\
\hline FE7 & 0.785 & 0.458 & 0.554 & 0.457 \\
\hline FL1 & 0.527 & 0.851 & 0.542 & 0.535 \\
\hline FL2 & 0.405 & 0.667 & 0.295 & 0.479 \\
\hline FL3 & 0.390 & 0.699 & 0.328 & 0.364 \\
\hline FL4 & 0.651 & 0.864 & 0.651 & 0.649 \\
\hline FL5 & 0.628 & 0.893 & 0.605 & 0.562 \\
\hline FL6 & 0.512 & 0.857 & 0.565 & 0.515 \\
\hline FL7 & 0.592 & 0.835 & 0.598 & 0.529 \\
\hline FS1 & 0.502 & 0.499 & 0.770 & 0.543 \\
\hline FS2 & 0.528 & 0.557 & 0.823 & 0.566 \\
\hline FS3 & 0.593 & 0.471 & 0.789 & 0.542 \\
\hline FS4 & 0.254 & 0.271 & 0.524 & 0.380 \\
\hline FS5 & 0.593 & 0.563 & 0.728 & 0.565 \\
\hline FS6 & 0.527 & 0.466 & 0.773 & 0.545 \\
\hline II1 & 0.464 & 0.563 & 0.521 & 0.707 \\
\hline II2 & 0.629 & 0.584 & 0.620 & 0.800 \\
\hline II3 & 0.334 & 0.299 & 0.319 & 0.669 \\
\hline II4 & 0.443 & 0.377 & 0.293 & 0.597 \\
\hline II5 & 0.538 & 0.551 & 0.626 & 0.833 \\
\hline II6 & 0.332 & 0.329 & 0.431 & 0.620 \\
\hline II7 & 0.465 & 0.463 & 0.645 & 0.799 \\
\hline
\end{tabular}




\section{Result of hypothesis testing}

The first hypothesis discusses the effect of financial socialization on investment intention. The t-statistics value for the first hypothesis is 3,380 (t-statistics $>1.96$ ) and the $\mathrm{p}$-value is 0.001 ( $\mathrm{p}$-value $<0.05$ ). From the analysis it can be concluded that the hypothesis is accepted with the conclusion that there is a significant positive effect between financial socialization and investment intention.

The second hypothesis discusses the effect of financial socialization on investment intention through financial literacy. The tstatistics value for the second hypothesis is 1.404 (t-statistics $<1.96)$ and the $p$-value is 0.161 ( $p$-value $>0.05)$. From the analysis it can be concluded that the hypothesis is rejected with the conclusion that there is no significant positive effect between financial socialization with investment intention through financial literacy as mediation.

The third hypothesis discusses the effect of financial experience on investment intention. The t-statistics value for the second hypothesis is 2.195 ( $\mathrm{t}$-statistics $>1.96$ ) and the $\mathrm{p}$-value is 0.029 ( $\mathrm{p}$-value $<0.05$ ). From the analysis it can be concluded that the hypothesis is accepted with the conclusion that there is a significant positive effect between financial experience and investment intention.

The fourth hypothesis discusses the effect of financial experience on investment intention through financial literacy. The tstatistics value for the second hypothesis is 1,980 ( $t$-statistics $>1.96)$ and the $p$-value is 0.048 ( $p$-value $<0.05$ ). From the analysis it can be concluded that the hypothesis is accepted with the conclusion that there is a significant positive effect between financial experience and investment intention through financial literacy as mediation.

The fifth hypothesis discusses the effect of financial socialization on financial literacy. The t-statistics value for the second hypothesis is 3.064 (t-statistics $>1.96$ ) and the p-value is 0.002 (p-value $<0.05$ ). From the analysis it can be concluded that the hypothesis is accepted with the conclusion that there is a significant positive effect between financial socialization and financial literacy.

The sixth hypothesis discusses the effect of financial experience on financial literacy. The t-statistics value for the second hypothesis is 3.524 ( $\mathrm{t}$-statistics $>1.96$ ) and the $\mathrm{p}$-value is 0 ( $\mathrm{p}$-value $<0.05$ ). From the analysis it can be concluded that the hypothesis is accepted with the conclusion that there is a significant positive effect between financial experience and financial literacy.

The seventh hypothesis discusses the effect of financial literacy on investment intention. The t-statistics value for the second hypothesis is 2.333 ( $\mathrm{t}$-statistics $>1.96$ ) and the $\mathrm{p}$-value is 0.020 (p-value $<0.05$ ). From the analysis it can be concluded that the hypothesis is accepted with the conclusion that there is a significant positive effect between financial literacy and financial investment intention.

Table 4

Direct and indirect effects

\begin{tabular}{clcc}
\hline Hypotheses & Effect & Direct Effect & Indirect Effect \\
\hline H1 & Financial Socialization $\rightarrow$ Investment Intention & 0.416 \\
H2 & Financial Socialization $\rightarrow$ Financial Literacy $\rightarrow$ Investment Intention & 0.089 & 0.001 \\
H3 & Financial Experience $\rightarrow$ Investment Intention & 0.161 \\
H4 & Financial Experience $\rightarrow$ Financial Literacy $\rightarrow$ Investment Intention & 0.100 & 0.200 \\
H5 & Financial Socialization $\rightarrow$ Financial Literacy & 0.029 & 0.048 \\
H6 & Financial Experience $\rightarrow$ Financial Literacy & 0.002 \\
H7 & Financial Literacy $\rightarrow$ Investment Intention & 0.000 \\
\hline
\end{tabular}

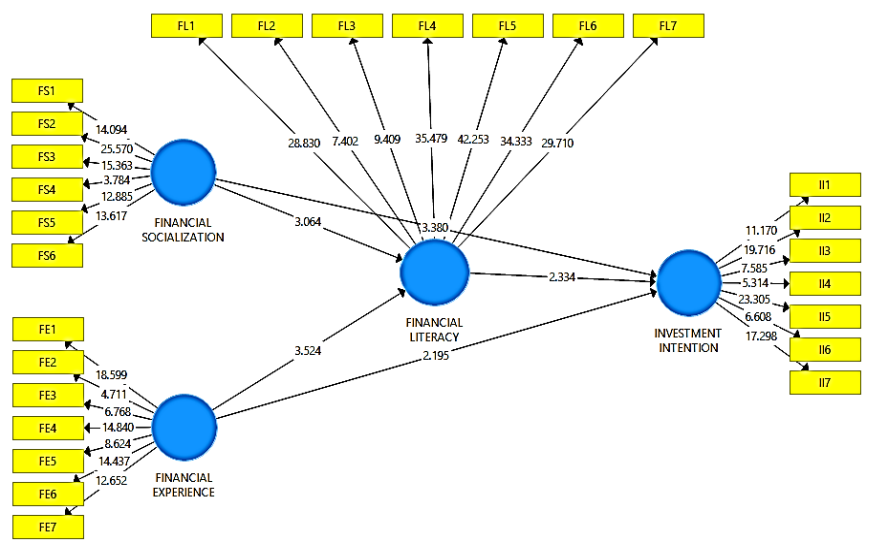

Fig. 2. Structural model — overall path diagram 


\section{Discussion}

The results of this study indicate that financial socialization has a positive effect on investment intention. This shows that the subject of this study is that students feel the role of social agents that influence their investment interests. Tarumanagara University Faculty of Economics and Business students already have knowledge of investment and have met the requirements to open a stock investment account in the capital market.

In measuring financial socialization, the FS2 indicator has the most influence, "in taking financial actions, the suggestions from my parents greatly influence my decision." From these results it can be illustrated that students can have an investment interest based on invitations or suggestions from social agents . Students still need external stimulation to be able to generate investment interest due to the lack of financial knowledge and experience. For these results it might be different if the respondents chosen were financial professionals who have a lot of financial knowledge and experience so as to generate investment interest from within themselves.

The results of this are in accordance with the theory of social learning theory, which says that a person will cause an intention to do something because of the role of social agents that help to generate such intentions so that in financial and investment terms there are social agents who provide examples of financial behavior indirectly can cause someone to follow it, including to invest.

The results of this study indicate that financial literacy cannot mediate financial socialization of investment intentions. In this study, the role of financial literacy as a mediation between financial socialization and investment intention is insignificant despite having a positive influence. This shows that to generate investment interest, solicitation or advice from social agents is more effective in generating investment interest.

In the measurement of financial literacy, FL5 indicator has the most influence "I always set aside some of my money for urgent purposes". From these results it is clear that someone who has a good level of financial literacy will be on guard about an uncertain future with one way to have his own savings for urgent needs. The role of social agents themselves becomes less effective in generating investment interest because someone with a good literacy level will be very difficult to be influenced by external stimuli to generate investment interest.

The results of this study have different results from the studies of Setiyani and Ameliawati (2018), Sohn et al (2012), Putri and Djuminah (2016) and Muhammad and Khan (2018). Although the results of this study have less significant results, the direction of the influence of financial socialization on investment intention through financial literacy has the same results, namely positive with previous research.

The results of this study indicate that there is a positive influence between financial experience on investment intention. The students of the Faculty of Economics and Business at Tarumanagara University already have sufficient financial experience so that it can generate interest in investing because they have experienced good financial experience themselves.

In the measurement of financial experience, FE1 is the indicator that gives the biggest impact "I have savings in the bank". From this it can be concluded that students already have basic experience in finance as indicated by experience in opening and having their own savings in the bank. Banking is the main entry point in the financial industry so that with a bank account it will be easier to conduct various other financial transactions such as to invest. So it can be concluded that to increase investment interest among students can be started with financial experience, namely opening a bank account. The more financial experience students have will certainly create a stronger impetus for investment interest.

The results in this study indicate that financial experience has a positive influence on investment intention through financial literacy. This shows that financial literacy can mediate financial experience towards investment intention. The level of financial literacy gained from student financial experience can generate investment interest.

In the measurement of financial literacy, FL5 indicator has the greatest impact "I always set aside a portion of my money for urgent purposes". This is in line with the basic student financial experience of having savings in a bank that can increase the level of financial literacy with the presence of banking savings so students can save by setting aside income for future needs and uncertainties. Students who are aware of uncertainty about the future will certainly have an awareness of the importance of investing to deal with uncertainty in the future so that it can generate interest in investing.

The results of this study are also in accordance with the research of Setiyani and Ameliawati (2018) which shows that financial literacy can mediate financial experience. In addition, Sadiq and Khan's research (2018), there is a positive influence between financial literacy and investment intention so that financial literacy can be used as a mediation between financial experience. 
The results of this study indicate that financial socialization can positively influence financial literacy. This shows that the presence of social agents can increase the level of financial literacy of the Tarumanagara University Faculty of Economics and Business students.

In the measurement of financial socialization, the FS2 indicator has the most influence "my parents direct me to always save". In this case, social agents will certainly be one source of channeling financial information that can increase the level of financial literacy of students. The more social agents that are owned, the more indirect financial information that can be received by someone who is useful to increase the level of financial literacy.

\section{Concluding remarks}

The results of this study are in accordance with the research of Setiyani and Ameliawati (2018), who said that financial socialization can affect financial literacy because with the presence of social agents can be one way to obtain good financial knowledge either through discussion or through short talk so that it can increase one's financial literacy level.

The results of this study indicate that financial experience has a significant effect on financial literacy. This shows that the more financial experience a person has, it can increase one's level of financial literacy. Measurement of financial experience, the FE1 indicator has the most influence "I have savings in the bank". This shows that the more experience a person has in conducting financial activities it can increase one's level of financial literacy. The main thing that becomes the basis for financial activities is opening a savings account at the bank after which it is possible to carry out other financial transactions.

This result is in accordance with the research of Setiyani and Ameliawati (2018) which shows that there is a positive influence between financial experience and financial literacy. In this research it is said that the more financial experience one has, the higher a person's level of financial literacy.

The results of this study indicate that financial literacy can have a positive influence on investment intention. This shows that the higher a person's level of financial literacy can lead to investment interest. In the measurement of financial literacy, the FL15 indicator has the most influence "I always set aside some of my money for urgent purposes". From this research it can be concluded that someone who understands financial literacy will certainly be aware of various kinds of uncertainties that will occur in the future so that it will certainly raise interest in investing as a way to deal with these uncertainties. The results of this study are consistent with research by Muhammad and Khan (2018), saying that there is a positive influence between financial literacy on investment intention.

Further research can include elements of herding behavior in the financial literacy model for the college students as the research object. This is because college students often make them each other a reference in thinking and acting. To transform herding behavior measurements into questionnaire items, we can include the studies from Ramli, et al. (2016) and Setyawan $\&$ Ramli (2016). What needs to be considered is how to transform its measurements so that relevant and accurate questionnaire items about herding behavior can be generated. In addition, the research model can be developed to be better by adopting elements of financial citizenship specifically for the female students from the study of Setyawan, et al. (2020).

\section{References}

Abdillah, W., \& Jogiyanto (2015). Partial Least Square (PLS), Alternatif Structural Equation Modeling (SEM) Dalam Penelitian Bisnis. Yogyakarta: Andi Offset.

Ajzen, I., \& Fishbein, M. (1977). Attitude-behavior relations: A theoretical analysis and review of empirical research. Psychological Bulletin, 84(5), 888..

Ali, A. (2011). Predicting individual investors' intention to invest: an experimental analysis of attitude as a mediator. International Journal of Human and Social Sciences, 6(1), 876-883..

Al-Tamimi, H. H., \& Bin Kalli, A. (2009). Financial literacy and investment decisions of UAE investors. Researchgate, 10(5), 500-516.

Ameliawati, M., \& Setiyani, R. (2018). The Influence of Financial Attitude, Financial Socialization, and Financial Experience to Financial Management Behavior with Financial Literacy as the Mediation Variable. KnE Social Science, 811-832.

Chin, W. (1998). The partial least squares approach to structural equation modeling. In G. A. Marcoulides (Ed.), Modern methods for business research. Lawrence Erlbaum Associates, 295-336.

Chin, W., \& Newsted, P. (1999). Structural equation modeling analysis with small samples using partial least squares. In R. H. Hoyle (Ed.), Statistical strategies for small sample research. Sage Publications, 307-341.

Copur, Z. (2015). EFFECTS OF FINANCIAL SOCIALIZATION AND PERCEIVED NORMS ON MATERIALISM: COLLEGE STUDENTS SAMPLE. Turkey: IGI Global.

Fulk, M., \& White, K. J. (2018). Exploring racial differences in financial socialization and related financial behaviors among Ohio college students. Cogent Social Sciences, 4(1), 1514681.

Ghozali, I., \& Latan, H. (2014). Partial least squares : konsep, teknik dan aplikasi SmartPLS 2.0 M3 untuk penelitian empiris. Semarang : Badan Penerbit Universitas Diponegoro. 
Hair, J. F., Ringle, C. M., \& Sarstedt, M. (2011). PLS-SEM: Indeed a silver bullet. Journal of Marketing theory and Practice, 19(2), 139-152.

Haming, M., \& Basalamah, S. (2010). Studi Kelayakan Investasi Proyek dan Bisnis. Jakarta Bumi Aksara, 14.

Henseler, J., Ringle, C. M., \& Sinkovics, R. R. (2009). The use of partial least squares path modeling in international marketing. In New challenges to international marketing. Emerald Group Publishing Limited.

Kumar, S., Watung, C., Eunike, J., \& Liunata, L. (2017). The Influence of financial literacy towards financial behavior and its implication on financial decisions: A survey of President University students in Cikarang-Bekasi. firm. Journal of Management Studies, 2(1), 169-177.

Lusardi, A., \& Tufano, P. (2015). Debt literacy, financial experiences, and overindebtedness. Journal of Pension Economics \& Finance, 14(4), 332-368.

MAHFUDH, M. (2014). FINANCIAL LITERACY AND INVESTMENT DECISONS IN KENYA: A CASE OF INDIVIDUAL INVESTORS IN THE NAIROBI SECURITIES EXCHANGE. Fall : UNITED STATES INTERNATIONAL UNIVERSITY.

Muhammad, M. N., \& Khan, R. A. (2018). Financial Literacy, Risk Perception and Investment Intention among Youth in Pakistan. International Journal of Management Sciences and Business Research, 85-93.

Palm, C. N. (2017). Financial Socialization's Impact on College Students' Credit Card Behavior. The Journal of Undergraduate Research, 15(1), 8.

Putri, B. K., \& Djuminah. (2016). Peran Agen Sosialisasi Finansial, PengalamanFinansial dan Perilaku Terhadap Uang Dalam Membentuk Literasi Finansial Pada Mahasiswa. Artikel Ilmiah, 1, 1-15.

Ramli, I., Agoes, S., \& Setyawan, I. R. (2016). Information Asymmetry And The Role Of Foreign Investors In Daily Transactions During The Crisis; A Study Of Herding In The Indonesian Stock Exchange. Journal of Applied Business Research (JABR), 32(1), 269-288. https://doi.org/10.19030/jabr.v32i1.10178

Sekaran, U., \& Bougie, R. (2013). Research Methods For Business: A Skill Building Approach. New York: John Wiley \& Sons.

Setiawan, E. (2019). Kamus Besar Bahasa Indonesia.

Setyawan, I. R., \& Ramli, I. (2016). Herding Behavior in the Indonesian Stock Exchange: The Roles and Contributions of Foreign Investors During the Period 2006 to 2011. Jurnal Pengurusan, 46, 125-135.https://doi.org/10.2139/ssrn.2313036

Setyawan, I.R., Ramli, I., \& Listyarti, I. (2020) Design Development of Financial Citizenship Model for Women in Indonesia, IOP Conf. Ser.: Mater. Sci. Eng. 1007012046

Setyawan IR (2020) Funding Sources Consideration in the Framework of Capital Structure Decision, International Journal of Innovation, Creativity and Change. www.ijicc.net Volume 12, Issue 8, 2020, 631-644.

Solheim, C. A., Zuiker, V. S., \& Levchenko, P. (2011). Financial socialization family pathways: Reflections from college students' narratives. Family Science Review, 16(2), 97-112.

Sohn, S., Joo, S., Grable, J. E., Lee, S., \& Kim, M. (2012). Adolescents' financial literacy: The role of financial socialization agents, financial experiences, and money attitudes in shaping financial literacy among South Korean youth. Journal of Adolescence, 35, 2005-2007.https://doi.org/10.1016/j.adolescence.2012.02.002 
(C) 2021 by the authors; licensee Growing Science, Canada. This is an open access article distributed under the terms and conditions of the Creative Commons Attribution (CC-BY) license (http://creativecommons.org/licenses/by/4.0/). 